\title{
Passion for saving lives: Turkey between 2012 and 2017
}

\author{
Murat Gultekin, Ankara, Turkey; Semra Hatice Turan, Ankara, Turkey; Guledal Boztas, Ankara, Turkey; Cansu Öztürk, \\ Ankara, Turkey and Ezgi Hacikamiloğlu, Ankara, Turkey
}

Turkey, as a Eurasian country, has made great strides in cancer care as a result of profound achievements between 2012 and 2017. Prior to 2012, the entire country had a cancer registry coverage of only $23.3 \%$. However, over 3 years, active cancer registry centers were implemented in all Turkish cities, which enabled $100 \%$ coverage by 2015. One of these centers had been affiliated to World Health OrganisationInternational Agency for Research on Cancer (WHO-IARC) and became one of the six international registry centers with responsibility for training all North Africa and Central Asian countries in cancer registry. Starting in 2016, the country had also become one of a select number countries that routinely analyses 5 -year survival rates for all cancers. ${ }^{1}$

In terms of prevention, in addition to strict tobacco, obesity, and salt-consumption
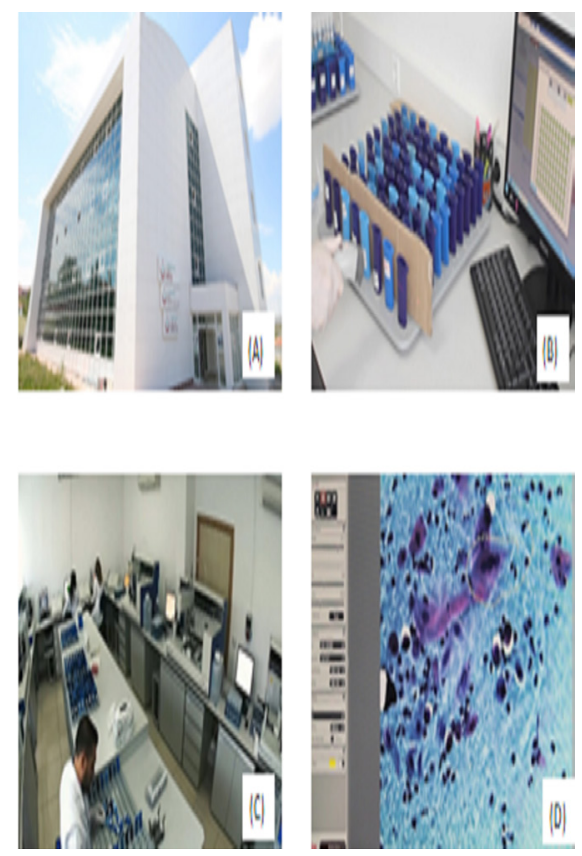

Figure 1 First Mega-HPV Laboratory in the World. 1A: Mega HPV Laboratory; 1B: Thousands of Pap-smear and HPV DNA samples come to the laboratory each day; 1C: HPV DNA screening machines; 1D: Reflex-smear digital pictures are stored.
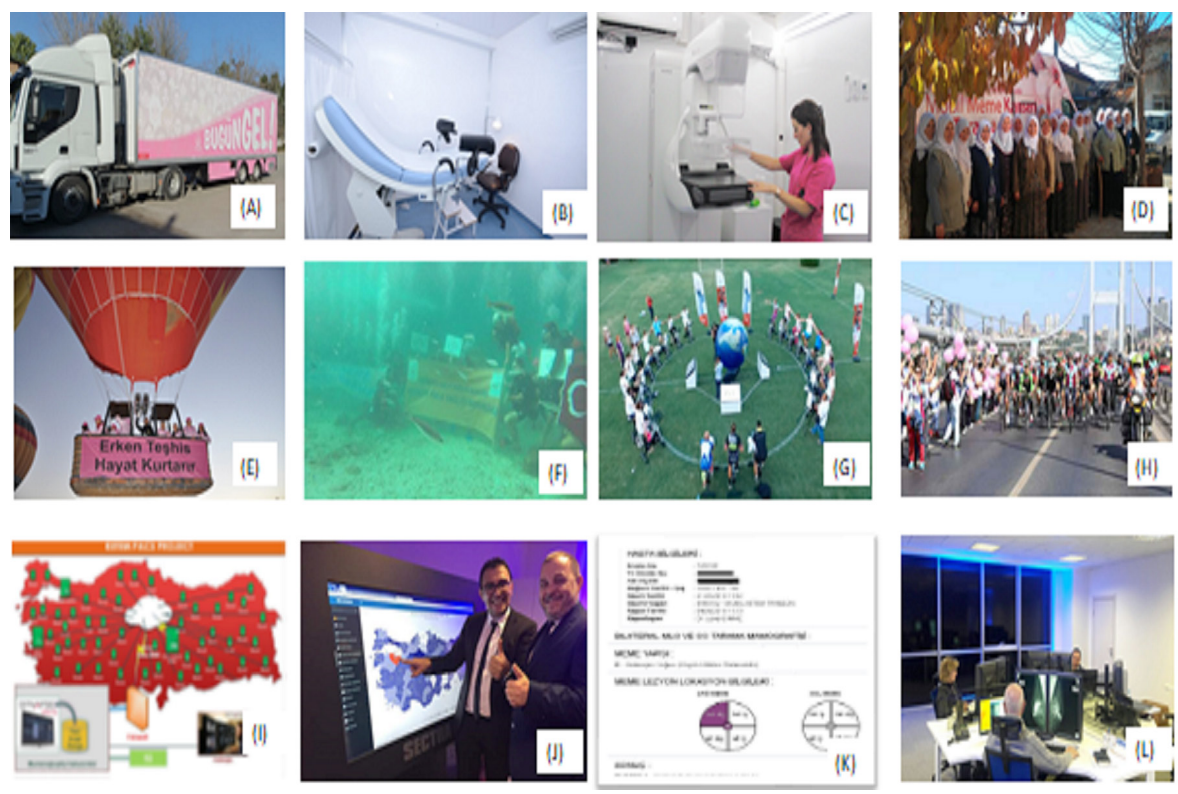

Figure 2 The world's first national 'out-sourcing mobile mammography and centralization of mammography reports project'; 2A-D: Mobile cancer screening trucks and mobilization of public; 2E-H: Impact awareness events; 2I-L: Central transfer of images and mammography reports.

reduction programmes, there are a number of active campaigns to monitor and evaluate the effects of asbestos, environmental pollution, and electromagnetic waves on our population. However, one of the most impactful changes has been the development of a successful cancer screening campaign. Turkey has become the first country in the world to have a primary HPV-DNA screening facility, with a mega-HPV laboratory serving the entire country $^{2}$ (Figure 1). In addition to a newlyimplemented HPV-DNA cervical screening programme, screening has also been implemented for colorectal and breast cancer. In addition to establishing colorectal screening, the country was again the first in the world to start using centralized mammography reporting, including the use of out-sourced mobile trucks ${ }^{3}$ (Figure 2).

Major innovations made in cancer screening (relating to the centralization of services) enabled Turkey to overcome barriers in quality assurance, low manpower and a lack of resources, and also to overcome economic burdens. In addition to these advantages, screening coverage rates have increased at least tenfold when compared with the previous systems. The Ministry of Health also included the PalliaTurk Project through the entire country, practiced at a community-based level and including general practitioners at the primary level. More than 700 homecare teams and 400 palliative care centers have been implemented around the country; together with specialised training and integration within the project of the local general practitioners who take care of these people, means that all cancer patients now have the chance to receive palliative care services either at their home or at the closest center to their homes. ${ }^{4}$ Also, through this project the domestic production of oral opioid tablets was started - and this has been followed by productions of dozens of national -chemotherapeutic drugs. ${ }^{5}$

The Ministry of Health's great efforts in raising its awareness has also played an invaluable role in the success of the 


\section{Corners of the world}

programme. To support all activities, the country also performed 'impact awareness events': these includied riding bicycles from Vienna to Ankara (through the Bosphorus Bridge between Europe and Asia) together with many more media-highlighted events, such as diving or flying in hot-air ballons for cancer (Figure 2). Each of these events produced a significant impact on the awareness for gynecological cancers among doctors, the public, and policy makers, and resulted in greater awareness of the cancer prevention programme and increased participation in the screening programme.

We are all proud of the country's change in cancer care, bridging Europe to other parts of the world. The country has not only had recent representation on the executive board of ESGO (European Scoiety of Gynaecological Oncology), but also IPRI (International Prevention Research Institute), APOCP (Asian Pasific Organization for Cancer Prevention), ANCCA (Asian National Cancer Centers Alliance), OIC (Organization of Islamic Cooperation), UICC (Union for International Cancer Control), and IARC (International Agency for Research on Cancer), and has carried out more than 150 international presentations. Additional efforts in gynecologic oncology have included the implementation of ENYGO (European Network of Young Gynae Oncologists), ENGAGe (European Network of Gyanecological Cancer Advocacy Groups), the ESGO Textbook of Gynecological Oncology, the ESGO Antalya State of Art Symposium on Prevention in 2016 (with 500 attendees), and the recent establishment of September 20th as World Gynecological Oncology Day (World GO Day, www.worldgoday.org) in more than 20 countries globally. Turkey also implemented

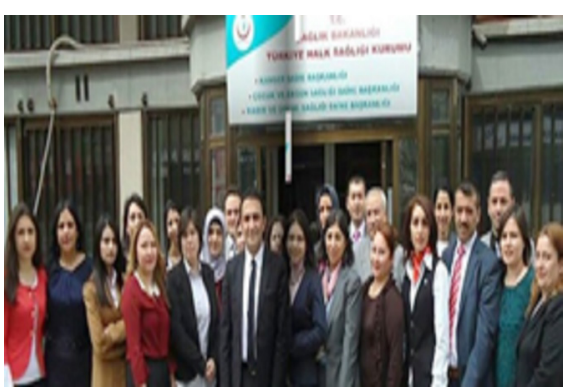

Figure 3 The young and motivated group of people who contributed to our success.

a new research group in Central-Asia (Russia, Iran, Kazakhstan, and Georgia) and in Eastern Europe (Belarus, Ukraine, and Greece) called CENT-EAST (www.centeast. com) and published the first SATEN-III multinational trial from those countries ${ }^{6}$ (which compared adjuvant treatment modalities to determine prognostic factors in 990 stage III endometrioid endometrial cancer patients, and showed improved survival with the use of systematic lymphadenectomy in adjuvant chemoradiotherapy).

The success of all of these initiatives in Turkey has been the direct result of the effort and motivation of young individuals who have envisioned a change for cancer care in the country. In addition, this would not have been possible without political support from the government, and lastly because of the great efforts from multi-national collaborators (Figure 3). Hopefully Turkey will continue to be a model of success in implementing change and new strategies in cancer care in the developing world, and that our efforts in this will continue.

Correspondence to Dr Murat Gultekin, Obstetrics and Gynecology, Hacettepe University Faculty of Medicine, Ankara, Turkey; mrtgultekin@yahoo.com
Contributors The manuscript writing was contributed to equally by all authors.

Funding The authors have not declared a specific grant for this research from any funding agency in the public, commercial or not-for-profit sectors.

Competing interests None declared.

Patient consent for publication Not required.

Provenance and peer review Not commissioned; externally peer reviewed.

(C) IGCS and ESG0 2020. No commercial re-use. See rights and permissions. Published by BMJ.

Check for updates

To cite Gultekin M, Turan SH, Boztas G, et al. Int J Gynecol Cancer 2020;30:709-710.

Accepted 5 November 2019

Published Online First 1 December 2019

Int J Gynecol Cancer 2020;30:709-710. doi:10.1136/ijgc-2019-001046

\section{REFERENCES}

1 Gultekin M, Dundar S, Kucukyildiz I, et al. Survival of gynecological cancers in Turkey: where are we at? J Gynecol Oncol 2017;28:e85.

2 Gultekin M, Karaca MZ, Kucukyildiz I, et al. Mega HPV laboratories for cervical cancer control: challenges and recommendations from a case study of Turkey. Papillomavirus Res 2019;7:118-22.

3 Gultekin M, Ozturk C, Karaca S, et al. Centralization of mammography reporting with mobile trucks: Turkish experience. Prev Med Rep 2018;10:317-22.

4 Hacıkamiloglu E, Utku ES, Cukurova Z, et al. Community palliative care in turkey: a collaborative promoter to a new concept in the middle East. $J$ Public Health Manag Pract 2016;22:81-8.

5 Kamu Hastaneleri Genel Müdürlüğü. Available: https://khgmozellikli.saglik.gov.tr/ svg/palyatif.php

6 Kahramanoglu I, Meydanli MM, Taranenka S, et al. SATEN III-Splitting Adjuvant Treatment of stage III ENdometrial cancers: an international, multicenter study. Int J Gynecol Cancer 2019;29:1271-9. 